\title{
On the Possibility of Using CHP From a 1.4MW Direct Fuel Cell at Kettering University Engineering Building - A Demonstration Study
}

\author{
${ }^{1}$ Etim U. Ubong, ${ }^{2}$ Uwem Ubong, ${ }^{1}$ Vipul Laddha, ${ }^{1}$ Pouyan Pourmovahed \\ ${ }^{1}$ Mechanical Engineering Department \\ Center for Fuel Cell Research \& Powertrain Integration \\ 1700 University Ave, Flint, MI USA. \\ Phone: +1-810- 762-7436, e-mail: eubong@kettering.edu; \\ ladd3387@kettering.edu; pour3112@kettering.edu \\ ${ }^{2}$ Department of Environmental Chemistry, Akwa Ibom University of Technology, A'Ibom State \\ Uyo, Nigeria \\ e-mail: uwembassey@yahoo.com
}

\begin{abstract}
The concept of using a distributed power generation and a combined heat and power principle - CHP in public buildings, commercial facilities is widely gaining public acceptance as a result of reduced energy cost, reliable power supply and environmental and health issues. By using the exhaust heat from a high temperature fuel cell at $400{ }^{\circ} \mathrm{C}$ for cogeneration, space heating, to provide warm water for facility use - (swimming pool and sporting locker room) and cooling in chillers at no additional cost, we reduce energy cost and preserve the environment. By bottoming cycle, the efficiency of the entire system is increased. A study is conducted to compare the economic impact of using the CHP system against the conventional heating system using furnaces.
\end{abstract}

\section{Key words}

Combined Heat and Power, Molten Carbonate Fuel Cell, Stationary power system, Pilot project, Economic analysis.

\section{Introduction}

The vision for the future distributed power system (DPS) is to produce localized power, generate power that use renewable source of energy and not necessarily be connected to the grid. DPS is a power system that can cogenerate for large industrial or commercial facilities and the products from the exhaust are benign to the atmosphere. These features are also desired in large institutions such as: universities, super-markets, large malls, credit card companies' headquarters, airports, immigration border crossings/posts, police precincts, hospitals etc. The merit of targeting large or small scale users are: freedom from power outage in case of natural disaster, such as the recent hurricane Sandy and disruption of commerce.

A combination of high temperature fuel cell and a turbo expander offers the best advantage of distributed power system in terms of efficiency, economics and environmental benefits. Combined heat and power implies the use of waste heat from a high temperature fuel cell - in this case, to generate additional power and the recovered heat is used for various heating and cooling purposes. The bottoming cycle is the use of the exhaust heat from the primary power plant to generate power in a secondary power unit. The waste heat (thermal energy) from the secondary power system is extracted. The heat can be harnessed and used for various applications, such as: (i) process analysis in factories and refineries, and (ii) providing warm water for residential facilities, especially high rise buildings. Further heat cycle is used in absorber chillers for air conditioning.

The rationale of using this power system includes using a single fuel source to generate electricity and the resulting waste heat is used for heating and cooling. The advantage is, in circumstances where winter storms or natural disaster, such as the one just experienced along the East Coast of the U.S.A., where hurricane Sandy downed power lines and over eight million people remained without power, distributed power with CHP could have been operating with or without minor power interruption.

The use of CHP has become widely used in many countries /1/. Different power systems can be used for bottoming cycle, such as: steam turbines, diesel power systems, etc. The current report focuses on CHP from a high temperature fuel cell operating at $400{ }^{\circ} \mathrm{C}$ based on Molten Carbonate Fuel Cell (MCFC), with the expansión turbine as the bottoming cycle. The objective of this report focuses on the economic impact of using high temperature fuel cell with cogeneration at the University Engineering building and comparing the cost with the grid based system. The environmental assessment in terms of eliminating the furnace in favor of $\mathrm{CHP}$ plant will be assessed. 
The concept of proliferation of CHP benefits to premium energy users such as credit card companies' headquarters, where one minute of power outage translates to billions of dollars losses makes an economic sense. Hospitals, food processing companies, airports, border crossings with immigration posts, police precincts, 911 emergency call centers, all require un-interruptible power sources, hence the essence of this research. The advantages are obvious (i) cost effectiveness as additional energy source is not required (ii) less vulnerability to seasonal energy price increase (iii) energy efficiency (iv) less noise, vibration and pollution, low maintenance (v) availability and reliability.

For the analysis of the CHP studies, some parameters are used as assessment matrix [1], such as:

* Estimated heat generation,

* Electrical power output Pe

* Exhaust temperature ${ }^{\circ} \mathrm{C}$

* Mass flow rate of fuel $\mathrm{kg} / \mathrm{s}$.

Only limited data will be published here.

The aim of this study is to analyze the power and heat requirement from the high temperature fuel cell (HT-FC) intended to replace the existing grid-fed power system and compare the economic benefits of one over the other. The fuel cell uses methane as fuel and produces direct electricity through indirect internal reformation of the fuel. The advantage of this power plant is that it is flexible and can use multi-fuels, such as, bio-fuels, methane, etc. Hydrogen is extracted from methane through steammethane reformation process.

Hydrogen is oxidized at the anode with the release of electrons. Carbon dioxide is formed in the process from the direct internal reformation at the anode. The $\mathrm{CO}_{2}$ is re-routed to the cathode where the supplied oxygen from air combines with carbon dioxide and electrons from the external circuit to form a mobile carbonate ion $\mathrm{CO}_{3}^{-2}$. The mobile carbonate ion passes through the electrolyte (a ceramic matrix) to the anode, where it reacts with hydrogen to form water, carbon dioxide with the release of electrons. One of the advantages of this HT-FC is the ability to internally reform the fuel at the anode.

\section{Project Review}

A power system with co-generation operates at a combined higher efficiency than the main power system acting alone. While the efficiency of the fuel cell (FC) system alone without the turbo-expander is put at $47 \%$ $/ 2$ /, more electricity can be generated by bottoming cycle, i.e., using the waste heat to produce mechanical power through turbo-expander-generator with the power increase up to $65 \%$. Other options possible are steam or gas turbine or any other heat engine to produce mechanical power. In this project, turbine expander (TE) connected to a generator is preferred. The reason is that it does not generate noise and is very suitable for this project. Considering the fact that it is going to be located near an academic building, the issue of noise a factor for consideration. Steam or gas turbine application is not considered in this Project.

To further optimize the heat utilization from the same fuel

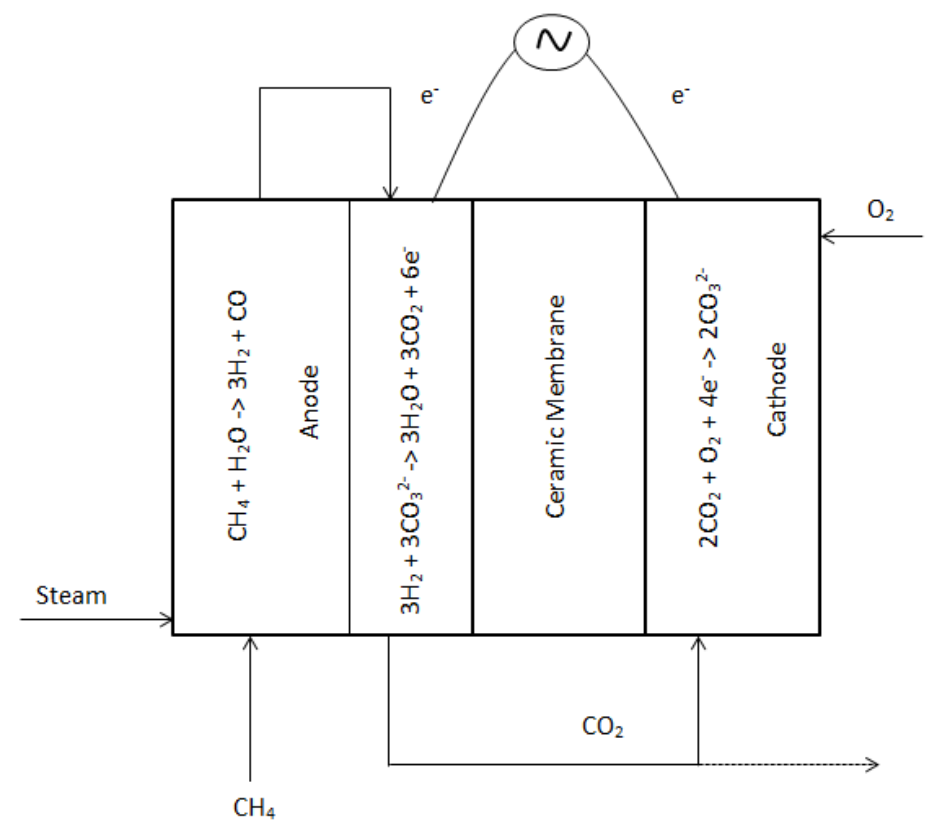

Figure 1. Schematic of the MCFC indirect Internal reformation process

source, the recovered heat is used for pinch technology, warming swimming pools, space heating and providing hot water to high-rise buildings and dormitories and cooling in absorbent chillers, etc. Using waste heat is an additional advantage as no additional fuel is required and polluting the environment with $\mathrm{CO}, \mathrm{NOx}, \mathrm{HC}$, particulates and green house gases (GHGs) from natural gas (NG) powered furnace is eliminated.

The CHP main power plant considered here is a Molten carbonate Fuel Cell-MCFC that uses molten carbonate salt placed in a ceramic matrix with an exhaust heat output from the anode at around $400{ }^{\circ} \mathrm{C}$. A turbine expander is directly powered by the exhaust heat from the -fuel cell. The schematic of the MCFC fuel cell with its indirect internal reformation process is shown in Figure 1 above. While Table 1 shows the Technical specifications of various fuel cells currently in use. Of interest are: fuel cell operating temperature, CHP capability and power range.

Figure 1 presents the schematic of the proposed project power module. The initial heat is derived from an endothermic reaction in the indirectly internally reformation process in the MCFC. Prior to that, the fuel is desulfurized in a column, before the sulfur free fuel is fed into the divided half of the anode of the fuel cell. The process follows the schematic shown in Figure 1. 
Table 1. Fuel Cell operating parameters /3/

\begin{tabular}{l|l|l|l|l|l|l|}
\hline Fuel Cell Type & PEM/DMFC & AFC & PAFC & MCFC & SOFC \\
\hline Operating & & & & & $600-$ \\
Temperature & $50-80^{\circ} \mathrm{C}$ & $90-100^{\circ} \mathrm{C}$ & $150-200^{\circ} \mathrm{C}$ & $600-700^{\circ} \mathrm{C}$ & $1000^{\circ} \mathrm{C}$ \\
\hline & & & $50 \mathrm{~kW}-1 \mathrm{MW} ;$ & & \\
Output & $>1 \mathrm{~kW}-250 \mathrm{k}$ & $10-100 \mathrm{~kW}$ & $(250 \mathrm{~kW}$ mod & $<1 \mathrm{~kW}-1.4 \mathrm{M})$ & $<1 \mathrm{~kW}-3 \mathrm{MW}$ \\
\hline & $53-58 \% *$ & & & & \\
Elect. efficiency & $25-35 \% * *$ & $60 \%$ & $>40 \%$ & $45-47 \%$ & $35-43 \%$ \\
\hline CHP Efficiency & $70-90 \% * * *$ & $>80 \%(\mathrm{LWH})$ & $>85 \%$ & $>80 \%$ & $<90 \%$ \\
\hline
\end{tabular}

The power system considered here can be described as electrical (FC) with Mechanical-electrical power system (bottoming cycle), in which the waste heat from the main power plant (FC) is used to operate turbine expander-TE, that is coupled to a generator. The exhaust of the TE is subjected to pinch analysis, etc., in which the waste heat from the FC is used to preheat the fuel and air (reactants) going into the desulfurizer and fuel cell cathode respectively. Part of the heated air is supplied to the furnace, to provide heat to promote endothermic reaction.

There are various reactions in the entire power plant that require heating or cooling. The exhaust heat from the FC is gainfully used to maximize the heat released in the system. The final heat rejected is routed into heat exchangers, for maintaining the temperature of swimming pools, hot water system and space heating. The rationale behind this approach is to extract the rejected heat and use it for other heating/cooling purposes eliminating the furnace-heater process. The advantages are overwhelming. It cuts down on cost of additional balance of plant and fuel and also final exhaust products are environmentally very malignant.

\section{Economic analysis and performance}

The proposed economic analysis is based on the fact that MCFC is the primary power unit. A bottoming cycle comprise the turbine expander (TE). The waste heat from the TE is used for various heating and cooling applications.

The total efficiency $\left(n_{\text {total }}\right)$ of the proposed model is summarized as:

$$
n_{\text {total }}=n_{\mathrm{FC}}+n_{\mathrm{TE}}
$$

where:

$\eta_{F C}$ is the efficiency of the MCFC fuel cell

$\eta_{\mathrm{TE}}$ is the efficiency of the TE

We use the coefficient of performance -COP to measure the performance of refrigerators and heat pumps
$\mathrm{COP}_{\mathrm{HP}}$ is the coefficient of performance (COP) of the heat pump used for heating

$\mathrm{COP}_{\mathrm{AC}}$ is the coefficient of performance of the absorption chiller used for cooling

Thermal efficiency is expressed as: work output/total heat input, whereas, the COP is the heat transferred from a low temperature or to a high temperature source divided by the work required to accomplish the heat transfer.

Thermal efficiency of the topping and bottoming cyles stand at $65 \%$ (i.e., FC plus TE). The COP of the absorber chiller which is used for cooling the building is unity. Which implies that little energy is used to provide work for the chillers. The energy comes from the fuel cell. For the heat pump, a compressed air hydraulically operated system is used. The device is a part of a pending patent.

Table 2. Fuel Cell Systems Costs /4/

\begin{tabular}{|c|c|}
\hline $\begin{array}{l}\text { Estimated Fuel Cell } \\
\text { System Costs - Fixed Cost } \\
\text { per year }\end{array}$ & USD (\$) \\
\hline $\begin{array}{l}\text { Capital Costs of } 1.4 \mathrm{MW} \\
\text { Fuel Cell system }\end{array}$ & \\
\hline Installation Costs & 295,933 \\
\hline $\begin{array}{l}\text { Commissioning Costs } \\
\text { (Start-up, Testing, } \\
\text { Tutorials for Operators) }\end{array}$ & 29,593 \\
\hline Shipping & 59,186 \\
\hline Payments & 516,000 \\
\hline $\begin{array}{l}\text { Fuel Cell System } \\
\text { Incentives }\end{array}$ & \\
\hline $\begin{array}{l}\text { Self-generation Incentive } \\
\text { program (SGIP) at } \\
\$ 2500 / \mathrm{kWe}\end{array}$ & 616,528 \\
\hline $\begin{array}{l}\text { Federal Investment Tax } \\
\text { Credit @ } \$ 3000 / \mathrm{kWe}\end{array}$ & 318,128 \\
\hline Total Yearly Fixed Costs & 773916 \\
\hline
\end{tabular}

Table 2 presents the overall cost of the system with tax credit from the Federal government. Michigan tax credit for those opting to use alternative fuel is not included here. A proposition was adopted after the 2012 election to give tax credit or incentive to institutions using renewable energy as a part of their power requirement. Table 3 provides the operating data requirement of the MCFC. From the above, we can make a simple comparison with the conventional system that uses compressed natural gas (CNG) for heating requirement of the building and a different balance of plant for the cooling system during the warmer months of the year. The yearly cost of electric and gas bills (for proprietary information protection reasons is not disclosed here), but is extremely colossal compared with the use of fuel cell with TE and waste heat utilization for heating and cooling. 


\section{DCF-ERG: PIPELINE TO ULTRA_CLEAN}

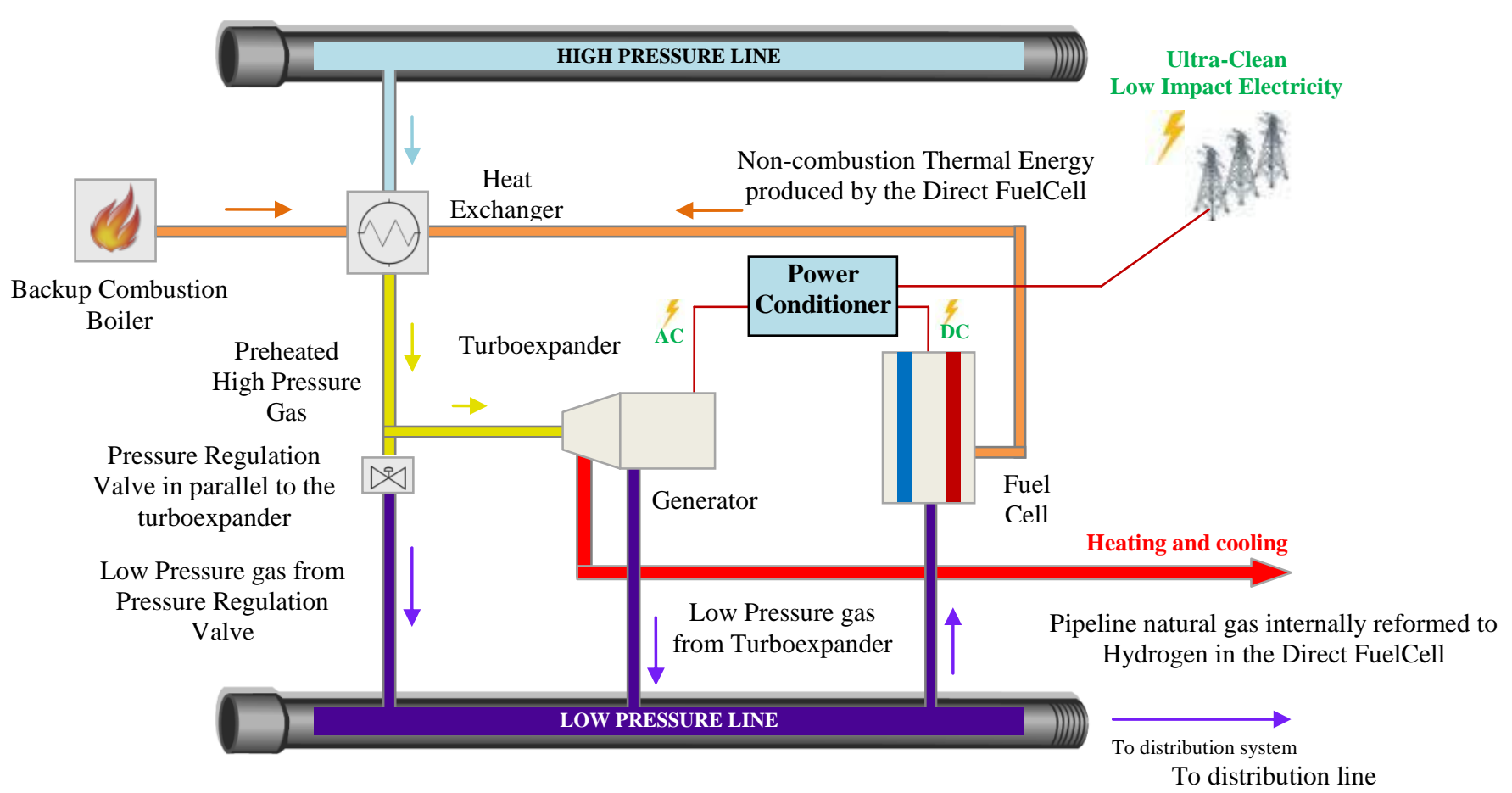

Figure 2. Schematic of the Proposed model. Courtesy of and Adapted from Ref. 2. Fuel Cell Energy.

Table 3. Fuel Cell System Operating Data /4/

\begin{tabular}{lcc}
\hline Maximum Electrical Output & 1400 & $\mathrm{~kW}$ \\
Minimum Electrical Output & - & $\mathrm{kW}$ \\
Maximum Heat-to-Electric & 1.884 & \\
Power Ratio & 0.9 & \\
Minimum Heat-to-Electric & & BTU of natural gas /kWh \\
Power Ratio & 9553 & \\
Natural Gas Fuel Consumption & & \\
(in Units of Energy) Per Unit of & & \\
Electric Output & $60 \%$ & \\
Electrical Efficiency & $0 \%$ to $40 \%$ & \\
Heat Recovery Efficiency & $40 \%$ & \\
Cooling Efficiency (for COP of 1) & $15 \%$ & \\
Heat Losses & $90 \%$ & \\
Combined Electrical and Heat & & \\
Recovery Efficiency &
\end{tabular}


A schematic of the topping and bottoming cycles are shown in Figure 2. The efficiency of a stand alone primary power system (FC) is $47 \%$. A combined efficiency of FC and the turbine expander is $67 \%$. The remaining $37 \%$ of thermal energy is used for cooling and heating bringing the Sankey diagram to $67 \%$ electricity, $9 \%$ heating, $10 \%$ cooling, fuel utilization efficiency of $4 \%$ and heat losses to the surroundings at $14 \%$

\subsection{The absorption chiller (AC)}

To optimize the rejected heat utilization an AC is incorporated in the model. The basic principle of the operation of $\mathrm{AC}$ is as follows. Unlike the conventional refrigeration system that uses refrigerants such as Chlorofluorocarbons-CHCs or HydrochlorofluorocarbonsHHCs; compressor, condenser, expansion valve and evaporator; the absorption chillers use waste heat from the $\mathrm{TE}$ to heat salt of lithium bromide $(\mathrm{LiBr})$ and water to produce chilled water $/ 5 /$. Thereafter, the two substances are separated through heat rejection. The heat addition and rejection is conducted at low pressures. The generated chilled water from salts of lithium bromide and water cools its medium from $6-12{ }^{\circ} \mathrm{C}$, which fits into the temperature range of our model for air-conditioning.

Some of the advantages of this approach are:

* gainful use of waste heat from the TE to aircondition buildings and facilities at no additional cost of fuel.

* the shift of cost of cooling from electricity based to thermal based thereby reducing electric bill.

* reduction of noise level which results from the absence of vibration of the rotating or moving components, qualifies it as a good distributed power balance of plant suitable for the academic environment.

* use of water as a refrigerant eliminates the cost of the conventional refrigerants. Concerns about leaking of $\mathrm{CHCs}$ and $\mathrm{HCHCs}$ into the atmosphere are eliminated.

* the system operates with a coefficient of performance (COP) of 1.0. COPs of electricity powered and engine driven compressors are 3.0 and 1.5 respectively $/ 5 /$.

An energy cost for the past five years with the central grid system will be used for cost analysis and comparisons with the distributed power system with CHP.

\section{Discussions}

A comparison of the monthly utility bill from electricity use and fuel gas shows that the use of a 1.4MW MCDC fuel cell will reduce environmental pollutions as follows [2]:
* NOx $=0.1 \mathrm{Ib} / \mathrm{MWh}$,
* $\mathrm{SOx}=0.0001 \mathrm{Ib} / \mathrm{MWh}$,
* particulates $=0.00002 \mathrm{Ib} / \mathrm{MWh}$
* $\mathrm{CO}_{2}$ (green house emissions) $=980 \mathrm{Ib} / \mathrm{MWh}$

* $\mathrm{CO}_{2}$ (green house emissions/with waste heat recovery) $=520-680 \mathrm{Ib} / \mathrm{MWh}$

The pollutants' figures above are far below the conventional power plant figures from furnaces and boiler systems. Tables 2 and 3 present the cost analysis of acquisition of the power unit. A comparison of the cost of CNG and monthly electric bill is far above the use of CHP for the model proposed for this project. The reduction of the electricity cost by approximately $40 \%$ with a cleaner exhaust justifies the use of this model for the university power system.

\section{Conclusions}

The net result is that, the use of high temperature fuel cell with direct internal reformation of methane with CHP reduces global $\mathrm{CO}_{2}$ emissions, as the $\mathrm{CO}_{2}$ formed in the reaction is fed back into the cathode for carbonate ion formation. The cost of additional fuel is eliminated. The carbon foot-print is reduced. The overall pollutants generated in these processes are far below pollutants levels from the gas fired furnaces. The noise level is within the acceptable limits.

\section{References}

[1]. Heather E. Dillon and Whitney G. Colella. Independent Evaluation of Measured Performance data for cutting-edge Combined Heat and Power Fuel Cell Systems Installed in Buildings. Proceedings of the ASME 2012 6th International Conference on Energy Sustainability- ES2012-91471. July 23-26, 2012, San Diego, CA, USA.

[2]. www.Fuelcellenergy.com

[3]. DOE Energy Efficiency \& Renewable Energy Center Publication 2010.

[4].Whitney G. Colella. Optimal Design and Control Strategies for Novel Combined heat and Power (CHP) Fuel Cell Systems: Part I Proceedings of the ASME 2012 6th International Conference on Energy SustainabilityES2010-33146. June 14-16, 2010, Brooklyn, N.Y, USA. [5].www.ge-energy.com/solutions/trigeneration.jsp 